DOI 10.15826/qr.2019.1.371

УДК 821.161.1-3Платонов+75.021.32+7.036

\author{
РЕВОЛЮЦИОННАЯ ТЕЛЕСНОСТЬ: \\ А. ПЛАТОНОВ И П. ФИЛОНОВ В ПОИСКАХ ДУШИ* \\ Юлия Подорога \\ Страсбургский университет, \\ Страсбург, Франция
}

\title{
REVOLUTIONARY CORPORALITY: PLATONOV AND FILONOV IN SEARCH OF THE SOUL
}

\author{
Iulia Podoroga \\ Strasbourg University, \\ Strasbourg, France
}

This article explores a new relationship between body and soul as exemplified by the prose of Andrey Platonov and the works (pictures and writings) of Pavel Filonov. According to the author's hypothesis, the revolutionary era provoked a shift in the harmonious union of body and soul, with the body becoming "deviant" in its apparent autonomy. This dissociation results in what is perceived as a manifestation of extreme naturalism in both authors' works. It seems that the independent life of matter in Filonov's works and the repulsive descriptions of the body in those by Platonov are signs of certain decadence, aesthetic formalism, avant-garde, or post avant-garde utopian experiment. In fact, a decomposing or suffering body (and not a body in the prime of life) appears disgusting because it is captured in its most extreme expression, but this is also why it is transient, i.e. it leads to something else-namely its metaphysical opposite, to the soul. Platonov hesitates between lack and excess in his representation of the body. The independent existence of the body results in its complete negation, and perhaps it is this particular "reduced" body that deviates from the norm the most. The excessive body cannot be thought of in complete separation from consciousness, even though consciousness and thought often appear blurred and are not put at the forefront of the narrative. Filonov analyses matter, dividing it into the smallest possible components. From the particular (bodily), the changing, the evolving, Filonov proceeds to the general

* Citation: Podoroga, I. (2019). Revolutionary Corporality: Platonov and Filonov in Search of the Soul. In Quaestio Rossica. Vol. 7, № 1. P. 187-202. DOI 10.15826/qr.2019.1.371.

Цитирование: Podoroga I. Revolutionary Corporality: Platonov and Filonov in Search of the Soul // Quaestio Rossica. Vol. 7. 2019. № 1. P. 187-202. DOI 10.15826/qr.2019.1.371 / Подорога Ю. Революционная телесность: А. Платонов и П. Филонов в поисках души // Quaestio Rossica. T. 7. 2019. № 1. C. 187-202. DOI 10.15826/qr.2019.1.371.

(С) Подорога Ю., 2019

Quaestio Rossica • Vol. 7 • 2019 • № 1, p. 187-202 
(spiritual), invariable, to the "formula" of material content. The body is an object of analysis that always leads to synthesis. Thus, synthesis is the key procedure for the reunion of body and soul in the case of Filonov. The dissociation of corporality and spirituality is only a stage in the elaboration of a new relationship aimed at the creation of a new man, and the body is only a reason to talk about the soul.

Keywords: Andrey Platonov; Pavel Filonov; body as an object of art; deviant body; body and soul; Russian Revolution of 1917.

Рассматривается проблема телесности в ее соотношении с душой/сознанием в прозе Андрея Платонова и полотнах Павла Филонова. В революционную эпоху, к которой принадлежат оба автора, происходит диссоциация гармонического союза между телом и душой, и тело представляется девиантным в своей кажущейся автономности. Диссоциация выливается в то, что мы воспринимаем у обоих авторов как проявление крайнего натурализма. Кажется, что независимая жизнь материи у Филонова и отталкивающие описания тела у Платонова - это признаки некоторого декадентства, эстетизма формы, авангардистского или поставангардистского утопического экспериментирования. На самом же деле разлагающееся или страдающее, изможденное тело (а совсем не тело в расцвете сил) представляется отвратительным, поскольку оно схватывается в самом крайнем выражении собственной телесности, но именно поэтому оно транзитивно, переходно, то есть ведет к чему-то другому, а именно - к своей метафизической противоположности, к душе. Платонов колеблется между недостатком и избытком в репрезентации телесности. Независимое существование тела ведет к его полному отрицанию, и, возможно, именно такое «умаленное» тело наиболее отклоняется от нормы. Тело избыточное не может мыслиться в полном отрыве от сознания, несмотря на то что зачастую сознание и мысль оказываются как бы стушеваны, не выносятся на авансцену повествования. Филонов проводит анализ материи, дробя ее на мельчайшие составляющие. От частного (телесного), изменяющегося, эволюционирующего Филонов движется к общему (духовному), неизменному, к «формуле» материального содержания. Тело есть объект анализа, всегда приводящего к синтезу. Синтетичность Филонова и является залогом воссоединения тела и души. Диссоциация же телесности и духовности - лишь этап в переосмыслении их отношений на пути к созданию нового человека, а само тело - только повод говорить о душе.

Ключевые слова: Андрей Платонов; Павел Филонов; тело как объект искусства; девиантное тело; тело и душа; революция 1917 г.

Телесность, о которой пойдет речь, приобретает свою специфику на фоне политических и социальных потрясений, наиболее ярким воплощением которых является революция. Как же мыслится телесность в связи с революцией, какую форму она принимает, можно ли считать ее девиантной, ненормативной, когда само понятие нормы претерпевает неизбежные изменения? В таком случае девиация-уже 
не отклонение от нормы, а индикатор трансформации телесности или обновления отношений между телом и душой (сознанием) в постреволюционное время. Речь скорее идет об изменении отношения к проявлениям телесного, то есть витальным отправлениям самого организма, его жизненным функциям и о возможности их подчинения идее революции как волевой трансформации зависимого от природы животного начала в человеке. Однако почти каждой революции сопутствует гражданская война, а значит, постоянная угроза уничтожения, насилие, смерть. Таким образом, одного волевого решения в отношении освобождения души от телесной зависимости (как и, наоборот, тела от души) недостаточно: само отношение к жизни и смерти не может оставаться прежним, что непосредственно затрагивает также и идею союза тела и души в постреволюционный переходный период. Тело, по-видимому, становится девиантным, когда теряет контакт с душой, когда установленное согласие «душа - тело» распадается. Можно сказать, что нормативен гармоничный союз тела и души, тело же, получающее самостоятельность, начинает жить по своим правилам, не подчиняясь более субъекту, индивидуальному сознанию, к которому его принято относить и которое оно должно выражать.

Ярко выраженный интерес к телу характерен как для Андрея Платонова, так и для Павла Филонова. Однако сравнение писателя и художника, словесного и визуального планов совсем не означает, что живописный образ отражает, как в зеркале, образ литературный, и наоборот. Совпадения тем, сюжетов, а также порой и приемов указывают на более глубинное родство, возникающее на уровне поставленной проблемы ${ }^{1}$. Именно в проблематике телесности мы находим «материальную» точку опоры, сводящую вместе две независимые художественные реальности - образ и текст. В рамках этой проблемы пересечения могут быть многочисленными. Это, в первую очередь, сходство устремлений-поиск средств выражения, направленных на новый объект. Новая реальность требует изобретения новых понятий: и Платонов, и Филонов пытаются создать язык, понятный пролетарию и разработанный для него ${ }^{2}$. Советская реальность вводит в обращение целый ряд общих понятий: коммунизм, революция, идеология, организация и т.д. Единственный способ их уяснения это их предельное овеществление: конкретизация в языке (Платонов) и визуальное наглядное изображение (Филонов). Персонажи Платонова пытаются присвоить себе общие понятия, перевести их на доступный язык, сравнить с чем-то известным, выразить в конкретной образной риторике. Насколько Платонов стремится наделить своих

${ }^{1}$ Этот подход можно назвать трансмедиальным, то есть таким, при котором различные медиа параллельно исследуют одну и ту же проблему или образ, используют сходные нарративные структуры и приемы. См., например: [Хаминова, Зильберман].

${ }^{2}$ Исследователь творчества Платонова Х. Гюнтер говорит о «низовом повествовании», обусловленном наивностью восприятия, культивируемого писателем [Гюнтер, с. 341]. Такой «примитивизм» свойствен не только Платонову, но и Филонову. 
персонажей суррогатным языком, состоящим из партийных штампов, развернутых в осязательные образы, настолько же и Филонов пытается устранить из своей «Идеологии ИЗО» всякое традиционное метафизическое измерение, связанное с творчеством и эстетикой, свести рисование к наиболее вещественной ремесленной деятельности. И в то же время его понятия-неологизмы сами по себе выглядят еще более сложными, чем традиционные: «идеология», «сделанные картины», «художник как пролетарий», «формулы» и т.д. Вследствие такого влечения к понятийному, к абстрактному обоих авторов отличает отсутствие интереса к индивидуальному, оба стремятся к изображению типов (рабочий, ударница, колхозник). Сама фигура пролетария не может пониматься иначе как тип нового человека.

Доминанта исследовательского интереса-присущая обоим амбивалентность в изображении телесного: аскетизм и провозглашение победы над плотью и повышенная концентрация на телесности и на материи - доведение ее до пределов. То, что одновременно отталкивает и интригует у обоих авторов, это, условно говоря, натурализм в изображении тела и телесности. У Платонова - его отстраненные описания различных отправлений человеческого тела, как бы механически им справляемых (в том числе и сексуальность), ужасов, связанных с голодом (каннибализм), с эпизодами физической расправы, тем более беспощадной, поскольку она лишена аффективного участия ${ }^{3}$. У Филонова ощущение жуткого в некоторых картинах достигается за счет использования «трупных» пигментов краски, он работает с изувеченной телесностью, с материей и формами ее распада, предлагает новое изображение человека (через иконографию голов, обнажающих структуру черепа). Однако натурализм обоих авторовне эстетическая позиция, а сознательный выбор, мотивированный антропологически и даже онтологически. Он напрямую связан с поисками целостности, нового согласия между телом и душой, в рамках которого идеал телесного аскетизма уживается с некоторой формой телесной избыточности.

\section{Платонов и «безучастная» телесность}

Герои Платонова живут во времени, заданном революцией как фундаментальным событием-началом новой эпохи, повлекшим за собой насилие с вытекающими отсюда голодом, нищенствованием, миграцией между городом и деревней. Однако само представле-

Ср., например: «В повествовании постоянно отмечаются телесные функции человека, причем описания выглядят подчеркнуто натуралистичными. Упоминание о пище переходит в тему человеческих нечистот, отходов, уборных и канализационных труб. Соединение людей часто описывается как совокупление» [Дмитровская, с. 145]. Или: «Яркий пример изображения изнуренного голодом тела находим в рассказе «Родина электричества» (позднее вошедшем в “Технический роман”), в котором дается шокирующее по своему натурализму описание засохшего голого тела старухи» [Гюнтер, с. 128]. 
ние о революции у Платонова не связано с историческим событием ${ }^{4}$, а развивается в специфическую идею, устанавливающую «революционное время» как вид безвременья, подвешенного времени - времени сохранения революционности и ее достижений ради грядущего коммунизма. Герои терпят телесные лишения в состоянии постоянного осознавания исключительности той эпохи, в какую они живут и действуют, и во имя нового идеала телесности, ею порожденного.

У раннего Платонова «революционная» телесность противопоставляется телесности «буржуазной». На смену философии буржуазии приходит философия пролетариата. Обе различно представляют себе духовно-телесное единство: тело (Платонов употребляет слово «пол»)-это душа буржуазии, сознание-душа пролетариата. Задача пролетариата - окончательно победить буржуазию, «подавить в своей крови древние горячие голоса страсти, освободить себя и родить в себе новую душу-пламенную победившую мысль» [Платонов, т. 8, с. 12]. Здесь присутствует и мысль об освобождении, неотделимая от революционного сознания, но под избавлением здесь подразумевается некоторый аскетический идеал. Если буржуазное тело живет половым влечением, не стараясь его преодолеть, и ничем не ограниченная сексуальность - его удел, то тело пролетариата должно быть всецело подчинено его воле, его сознание стремится освободиться от тела. Таким образом, стратегия насильственного умаления тела должна привести к обнажению души. Точнее, душа или сознание обнаруживают себя только в противопоставлении телу5. Чистая мысль предполагает, таким образом, телесное существование, сведенное к минимуму. Это ярко представлено в более поздних произведениях Платонова:

Он [Дванов] с беспокойством присмотрелся к Гопнеру, пожилому и сухожильному человеку, почти целиком съеденному сорокалетней работой. $<. .>$ Когда Гопнер раздевался в бане, он, наверное, походил на мальчика, но на самом деле Гопнер был стоек, силен и терпелив, как редкий. Долгая работа жадно съедала и съела тело Гопнера-осталось то, что и в могиле долго лежит: кость да волос; жизнь его, утрачивая всякие вожделения, подсушенная утюгом труда, сжалась в одно сосредоточенное сознание, которое засветило глаза Гопнера позднею страстью голого ума (здесь и далее курсив в текстах мой.-Ю. П.) [Платонов, т. 3, с. 178].

В данном пассаже тело живет исключительно настоящим. Оно стоически претерпевает все изменения, подвержено риску, может в любой момент погибнуть, исчезнуть, оно живет на грани, готовое

4 По выражению Леонида Геллера, у Платонова «революция-не конкретное, замкнутое во времени историческое событие, но состояние мира-его динамика во времени, в природе, в космосе, в истории» [Геллер, с. 8].

${ }^{5}$ Сходная мысль выражена у М. Дмитровской: «Поиск настоящей души ведется по линии отталкивания от всепроникающей телесности, в которой нет ничего карнавального: она мрачна и отмечена печатью безысходности» [Дмитровская, с. 145]. 
отдаться без остатка идее революции. Тело, сведенное на нет, должно непременно обнажить душу, представить ее в своей незащищенности, тем самым открыть «голый ум», бестелесное сознание. Гопнер отрицает хлеб как излишек, несовместимый с революцией:

...будет хлеб и имущество - никакого человека не появится! Какая же тебе свобода, когда у каждого хлеб в пузе киснет, а ты за ним своим сердцем следишь! Мысль любит легкость и горе... [Платонов, т. 3, с. 175].

Предельное сведение на нет тела - это смерть. Именно в момент наступающей смерти желание осознавать наиболее остро. Сознание более ничем не отягощено, абсолютно свободно, но всего лишь на миг. Но именно этот миг герои Платонова переживают как вечность:

У Афонина три пули защемились сердцем, но он лежал живым и сознающим. Он видел синий воздух и тонкий поток пуль в нем. За каждой пулей он мог следить отдельно-с такой остротой и бдительностью он подразумевал совершающееся. «Ведь я умираю - мои все умерли давно!»- подумал Афонин и пожелал отрезать себе голову от разрущенного пулями сердиа -для дальнейшего сознания [Там же, т. 2, с. 227].

Все пространство повествования в этом отрывке захвачено нарастающим по своей силе сознанием. Голова нужна Афонину только как орган осознавания, а не как часть живого тела. При этом поражает безучастность умирающего тела, оно как бы не чувствует, что умирает. Тела у Платонова не способны переживать собственные страдания ни в момент умирания, ни в связи с голоданием, слабостью или болезнью. Отсюда ощущение жути от тел, похожих на живые «автоматы» [Подорога, с. 279].

Однако умаление тела не всегда приводит к прозрачности и одухотворенности мысли. Если зачастую главные персонажи Платонова способны переносить голод и лишения во имя высокой идеи, то народные массы описываются в основном как абсолютно обездоленные, так как у них не осталось ничего, кроме стремления к выживанию, как в описании народа джан:

Как назывался этот народ, ты не помнишь?

- Он не назывался,- ответил Чагатаев.-Но сам себе он дал маленькое имя.

- Какое его имя?

- Джан. Это означает душу или милую жизнь. У народа ничего не было, кроме души и милой жизни, которую ему дали женщины-матери, потому что они его родили.

Секретарь нахмурился и сделался опечаленным.

- Значит, все его имущество - одно сердце в груди, и то когда оно бьется...

- Одно сердце,-согласился Чагатаев,-одна только жизнь; за краем тела ничего ему не принадлежит. Но и жизнь была не его, ему она только казалась [Платонов, т. 4, с. 131]. 
Душа здесь не равнозначна сознанию, она скорее является синонимом жизни/телесности. Хотя в последней строчке, чтобы указать на самое отчаянное положение этого народа, Чаготаев называет его существование «кажущейся» жизнью - выживанием. Этот постоянно скитающийся, опустившийся народ, пытающийся лишь прокормиться, не вынес бы и малейшего усилия осознания:

Но какое сновидение питало сознание всего этого бредущего народа, если он мог терпеть свою судьбу? Истиной он жить не мог, он бы умер сразу от печали, если бы знал истину про себя. Однако люди живут от рождения, а не от ума и истины, и пока бьется их сердие, оно срабатывает и раздробляет их отчаяние и само разрушается, теряя в терпении и работе свое вещество [Там же, т. 4, с. 169].

По сути, перед нами ситуация, противоположная описанной выше, где наступающая смерть пробуждает и обостряет сознание: народ джан выживает из последних сил, и для этого ему необходимо только поддержание элементарных телесных процессов ${ }^{6}$. В его положении сознавание несет смерть.

Но проблема не только в теле. Истощение тела и тоска, томление души - бинарная оппозиция, организующая платоновский нарратив. Как тело, так и душа должны пройти через эти состояния, чтобы сделать возможным коммунистическое будущее. Обсуждая тему насыщения и голода у Платонова, Х. Гюнтер подчеркивает на примере повести «Джан», что минимум питания должен обеспечить встречу между телом и душой, ведущей к обретению гармонии [Гюнтер]:

Но тоска их может превратиться в радость, если каждый получит щипаный кусочек птичьего мяса. Это послужит не для сытости, а для соединения с общей жизнью и друг с другом, оно смажет своим салом скрипящие, сохнущие кости их скелета, оно даст им чувство действительности, и они вспомнят свое существование. Здесь еда служит сразу для питания души и для того, чтобы опустевшие смирные глаза снова заблестели и увидели рассеянный свет солнца на земле [Платонов, т. 4, с. 188-189].

Нужда, голод индивидуализируют тело, отделяют его от существования в коллективе, необходимого для воплощения коммунистического идеала. Но народ джан может еще оправиться от своего телесного забытья, вернуться к утраченному сознанию. Стоит ему только освободиться от давящей зависимости от собственного тела, обеспечить себе необходимый минимум пропитания, как общность жизни будет восстановлена. Душевная тоска сойдет на нет, как только телесные силы немного окрепнут.

\footnotetext{
${ }^{6}$ Борис Гаспаров относит интерес Платонова к такого рода натуралистическому описанию телесности к традиции физиологического очерка XIX в., приводя в параллель творчество Федора Решетникова, см.: [Гаспаров, с. 190-191].
} 
Мы сталкиваемся у Платонова с осмыслением и такой ситуации, при которой телесная жизнь развивается независимо по отношению к душе или сознанию - но в этот раз не по причине голода, а в связи с угрозой неминуемой смерти на фоне Гражданской войны:

Они еще не знали ценности жизни, и поэтому им была неизвестна трусость-жалость потерять свое тело. Из детства они вышли в войну, не пережив ни любви, ни наслаждения мыслью, ни созерцания того неимоверного мира, где они находились. < ...> Поэтому красноармейцы не имели в душе цепей, которые приковывали бы их внимание к своей личности. Поэтому они жили полной общей жизнью с природой и историей,-и история бежала в те годы, как паровоз, таща за собой на подъем всемирный груз нищеты, отчаяния и смиренной косности [Платонов, т. 2, с. 186].

В отличие от народа джан, красноармейцы причастны к общей жизни, общему телу истории и природы, но только потому, что им не известно ничто другое. Их жизненный опыт сводится к опыту войны и подчинен ходу истории. Их тело не осознает самое себя, оно природно, естественно, это предсознательное тело. Оно свободно своей пустотой и поэтому ощущает себя предельно легким даже в момент смерти.

На основании этих примеров можно сформулировать следующие сдвиги телесного по отношению к духовному. В случае Гопнера речь идет об изможденном от голода, практически исчезнувшем теле, преодолевшем самое себя во имя души. Афонин переживает подобное состояние, но не самовольно, а в момент насильственной смерти (момент смерти как преодоления телесности, а не подчинения ей). Народ джан скитается и ищет себе пропитание, живет исключительно телесной жизнью, ощущая постоянный недостаток этой ущербной телесности, не способной жить, но только выживать. Красноармейцы не делают различия между жизнью и смертью, между природой и культурой, между телом и сознанием. Они живут, сливаясь с природой, их душа не несет бремя сознавания, а тело-бремя лишений. Однако в первом случае мы встречаем «постсознательные», насильственно индивидуализированные, разобщенные тела, тогда как во втором речь идет о предсознательных общих коллективных телах.

Таким образом, наличие души, сознания совсем не является для Платонова условием существования тела. В его романах можно встретить по крайней мере три разных функции телесности: 1) обнажающей сознание (в том теле, которое мы называем революционным); 2) доминирующей и подавляющей сознание; 3) существующей независимо от сознания. Первая телесность позитивна в своем устремлении: чем больше она затронута, тем явнее проступает сознание. Ее ненормативность, девиантность заключается в подчеркнутой бесчувственности: то, что мы называем телесным страданием, не ощущается как таковое, то есть не есть недостаток телесности, а, совсем наоборот, ее переизбыток (аскетическое тело Гопнера избыточно в своем 
мученичестве, а тело Афонина-в своем умирании). В некоторых случаях, правда, Платонов допускает дефицит телесности, как в примере с повестью «Джан» или с красноармейцами из «Сокровенного человека». В момент пароксизма, когда голод до предела истощает человека, доступ к душе, к сознанию оказывается вдруг полностью отрезан. Происходит как бы двойная ампутация - как телесного, так и духовного. Такая телесность, не отсылающая к духовному, существует не в форме избытка, а в форме абсолютного недостатка.

\section{«Головы» Филонова: от материального - к духовному}

Искажение телесного образа с целью получения доступа к душе позволяет сблизить литературный проект Платонова с живописной доктриной Филонова, с его аналитическим интуитивным видением. Уже в ранний дореволюционный период такие картины Филонова, как «Мужчина и женщина» (1912-1913) или «Пир королей» (1913), вызывают недоумение критиков. Один из первых обзоров живописных полотен Филонова появляется по случаю «Выставки картин внепартийного Общества художников» в Петербурге в 1913 г. Видимо, как раз по поводу «Пира королей» в нем сказано: «У Филонова - трюк хирургический, ободрана кожа с красно-синих фигур, дан противный рисунок из анатомического атласа» [Б. А., с. 7]. Вероятно, в отношении той же картины известный критик Александр Ростиславов отмечает патологически болезненный характер «как бы политых свежей кровью» полотен Филонова (цит. по: [Филонов. Художник. Исследователь. Учитель, с. 32]). Его декорации к трагедии «Владимир Маяковский» описываются другими критиками примерно в тех же словах: уродливые фигуры, похожие на зародышей, «обезьяньего лица женщины», «дикого вида мужчины», а сама композиция напоминает лубочные изображения «геенны огненной» [Там же, с. 34]. В его живописи, таким образом, усматривают лишь футуристический прием, экспериментирование с формой в духе европейского авангарда и течений неопримитивизма. И в то же время другие комментаторы видят в картине символический смысл - апокалиптическое настроение, сопутствующее образам физического распада и смерти, и приписывают их влиянию немецкого экспрессионизма7. Действительно, в ранних

7 «В поисках творческого направления, к которому можно было бы отнести Филонова, всякий, кто хотя бы в какой-то мере знает расстановку сил в художественной культуре начала XX века, обращает свой взор к экспрессионизму (хотя кубизм и футуризм тоже достойны в этом плане некоторого внимания). И здесь мы вновь сталкиваемся с уже знакомой ситуацией: близость и отдаленность, сходство и противоположность. Многие тематические общности - город (Филонов и немецкие экспрессионисты), человек и город (Филонов - Мейднер - Гросс), библейские мотивы (Филонов-Нольде), человекоподобные звери (Филонов-Марк), человеческая жестокость (Филонов - Бекман), тяготение к неомифологизму (Филонов - Кокошка), общая обостренность мировосприятия-все эти и, наверное, другие черты свидетельствуют об известной близости, о том, что Филонов и экспрессионисты имеют некую общую историко-культурную почву» [Сарабьянов, с. 385]. 
картинах Филонова в образах смерти уже присутствует идея перерождения, никак не связанная с революционным переломом в мировоззрении. По крайней мере, так можно объяснить тот факт, что сам Филонов задним числом включит эту картину в цикл, придуманный им гораздо позже, уже после революции, под названием «МирОвый расцвет», который принято связывать с его представлением о революции как глобальном мировом явлении.

Конечно, можно согласиться, что тема физического уродства, изображение калек свойственны как реалистической, так и европейской экспрессионистской живописи. Кроме того, уродство буржуазного, безусловно, дань советской пропаганде. Но и филоновские пролетарий, рабочий или крестьянин не отличаются красотой ${ }^{8}$. Достаточно взглянуть на дореволюционные работы «Те, кому нечего терять» (1911-1912), «Коровницы» (1914), «Перерождение человека» (19141915), «Ломовые» (1915) или на пореволюционные, такие как «Люди в городе» (ок. 1920), «Кабак» (1924), «На рынке» (1923-1924) и более поздние «Колхозник» (1931) и «Рабочий в кепке» (ок. 1930). Заметим, что эстетизм изображения напрочь изгнан из риторики Филонова. Задача Филонова, как, собственно, и Платонова - не шокировать или эпатировать читателя. Через лишенное кожи, разъятое, расчлененное тело Филонов хочет добиться изображения жизни в ее органической и духовной целостности. То, что кажется физическим уродством, является на самом деле эволюционирующей формой человека, которая еще не знает, чем она станет, и поэтому стремится вобрать в себя весь мир во всех его проявлениях.

В этой связи любопытно замечание М. Матюшина:

Мир стал населен не распыленным человечеством, а великим общим телом Бога. Жизнь этого тела пошла по новым законам внутреннего склада. Не для показа стали творить, а велением духа, для путей нового тела [Матюшин, с. 232-233].

Картина предельно насыщена и осязаема, из нее как бы изливается материя. Собственно, согласно Матюшину, она сама есть тело, поскольку живет и развивается по законам органической материи. Эта жизнь должна быть «общая» для всех. Новый человек, пролетарий, это совершенный человек, и потому должен быть наделен самими характерными типическими чертами. У Филонова ведется поиск общего тела и человека как типа. С этим связан его интерес к головам, как, собственно говоря, и разработка концепции формул. Здесь его живописная теория снова соприкасается с некоторыми идеями Платонова. Достаточно вспомнить цитату из повести «Джан» о воскресении народа через еду - о возвращении его к «общей» жизни.

${ }^{8} \mathrm{O}$ «необыкновенном уродстве» картин Филонова как основной причине его неприятия на Западе говорит и Джон Боулт, см.: [Bowlt, p. 283]. 
Амбивалентность в отношении к телесности и даже противоречивость исходных принципов свойственны и Филонову: несомненный аскетизм, вытеснение телесного (художник должен довольствоваться только самым малым, не спать и не есть, а только упорно работать, вырисовывая каждый атом), с одной стороны, и в то же время стремление к целостности, к слиянию с миром через избыточную телесность, бьющую через край физическую, материальную жизненность. Как же сочетаются у Филонова абстрактность образов, их «идейность» (аскетизм в работе-одна из таких идей) и даже большевистская идеологичность (если судить по названиям его картин в постреволюционный период ${ }^{9}$ ) с натуралистическим способом представления?

Рассмотрим сначала картину 1923 г. под названием «Живая голова». Согласно каталогу «Выставки петроградских художников всех направлений 1919-1923», ее первоначальное название-«Голова в бытии процесса становления». Само выражение уже звучит парадоксально: голова находится одновременно в бытии - то есть не изменяется, подчинена определенным законам-и в процессе становления, эволюции. Но можно избежать парадокса, предположив, что для Филонова процессуальность, становление и есть само бытие. Иными словами, бытие заключается в становлении. Исследователи отмечают, что речь идет как бы о эволюции в обратном направлении - головы эволюционируют в сторону их «полного разложения: структурного, физиологического, вплоть до достижения первозданного клеточного состояния, своего рода биокультуры для зарождения новых растительных и животных организмов» [Мислер, с. 43]. Нам же кажется, что совсем не обязательно, всматриваясь в пустые глазницы и черепа, задаваться вопросом о направлении эволюции в сторону разложения или последовательного усложнения. Филонов пытается через микроскопический анализ тканей тела, анализируя каждый мускул и каждую клетку, достичь высшего синтеза, построенного не на схематической репрезентации тела, а на его дотошном физическом расчленении. Голова подвергается физическому разложению ради обнажения «вместилища мысли» [Там же]. То, чем, условно говоря, «кишит» голова, это не только микроорганизмы и бактерии, но и мысли. «Живая голова» 1923 г. еще довольно абстрактна по сравнению, к примеру, с «Головой», написанной в 1930-е гг., которая своей реалистичностью производит достаточно неприятное впечатление. Голова сине-красной трупной тональности обнажает кости черепа, в особенности глазницы и носовую впадину, на шее проступают все мышцы и сухожилия, как будто бы в задачи Филонова входило изобразить анатомическое экорше

\footnotetext{
${ }^{9}$ Следует заметить, что все анализируемые нами работы принадлежат второму периоду творчества Филонова после революции (1919-1929/30), в то время как у Платонова мы опирались в основном на тексты первого периода. См. о периодизации творчества Филонова: [Махов].
} 
человеческого бюста ${ }^{10}$. Таким образом, мы имеем дело с убеждением, которое мы встречаем и у Платонова, что мысль и идея могут быть представлены осязаемо, материально, на каком-то клеточном или даже нейронном уровне.

Несмотря на нарастание абстрактных элементов в живописи Филонова-тенденция, наиболее полно реализованная в цикле «формул», - представление человека у него практически всегда фигуративно. Помимо серии реалистических «красивых» портретов в голландском духе (речь идет в основном о семейных портретах), ориентированных не на типическое, а на индивидуальное, «головы», а также жанровые сцены (человек и виды его деятельности, среда обитания и окружение) преследуют цель изображения типического, то есть сущности, общей идеи изображаемого явления. Для этого необходимо найти новое живописное решение, новую форму, предполагающую сдвиг по отношению к фигуративному реалистическому изображению. По выражению Филонова, художник должен действовать «изобретенной формой» (письмо Вере Шолпо) [Филонов. Художник. Исследователь. Учитель, с. 197]. Собственно говоря, задача художника - изображение не феноменов (вещей и явлений окружающего нас мира так, как их воспринимает «глаз видящий»), а их понятий, то есть того, как интеллект их постигает и представляет («глаз знающий»). Уродливость, неприглядность «изобретенной формы»-это, таким образом, результат сдвига, практикуемого художником в отношении реалистического канона видящего глаза. Как утверждает сам Филонов:

Всякий видит под известным углом зрения, с одной стороны и до известной степени, либо спину, либо лицо объекта, всегда часть того, на что смотрит, дальше этого не берет самый зоркий видящий глаз, но знающий глаз исследователя, изобретателя-мастера аналитического искусствастремится к <абсолютному, наибольшему, полнейшему> исчерпывающему видению, поскольку это возможно для человека; он смотрит своим анализом и мозгом и им видит там, где вообще не берет глаз художника. Так, например, можно, видя только ствол, ветви, листья и цветы, допустим, яблони, в то же время знать или, анализируя, стремиться узнать, как берут и поглощают усики корней соки почвы, как эти соки бегут по клеточкам древесины вверх, как они распределяются в постоянной реакции на свет и тепло, перерабатываются и превращаются в атомистическую структуру ствола и ветвей, в зеленые листья, в белые с красным цветы, в зелено-желто-розовые яблоки и в грубую кору дерева. Именно это должно интересовать мастера <в первую очередь >, а не <видовая, известная, видимая> внешность яблони (цит. по: [Филонов. Художник. Исследователь. Учитель, с. 161]).

${ }^{10}$ Можно даже выделить тему «жуткого» в творчестве Филонова, связанную с репрезентацией «смертной плоти», а также «расчлененной и/или усеченной телесности». См.: [Злыднева, с. 172]. 
И в дополнение к этой цитате, акцентирующей биологическое измерение жизни, вот как в одной из рукописей без точной датировки и без названия (написанной не ранее 1923 г.) он формулирует ее интеллектуальное и видовое значение:

Так как творчество, т. е. сделанность, что бы ни изображалось на картине, прежде всего есть отображение через материал и фиксация через материал борьбы за становление высшим интеллектуальным видом человека и борьба за существование этого психологического вида, этому же равна и действующая сила искусства на зрителя, то есть она и делает высшее, и зовет стать высшим (цит. по: [Там же, с. 99-100]).

Представление распада и тления, отталкивающий характер изображения человеческих фигур-побочный продукт высшего устремления: от сложности, комплексности формы, материальной насыщенности - к простоте ее выражения, к единству живописной формулы ${ }^{11}$.

Собственно, Филонов пытается совершить парадоксальный прыжок из материального в идеальное. Только так можно понять кажущееся невозможным сочетание между чистой установкой на интеллект и использованием натуралистической разлагающейся формы. С одной стороны, Филонов настаивает на чисто интеллектуальном значении своей живописи:

...живопись есть определенный и точный язык, которым действует интеллект и которым он высказывает то, что речь как таковая высказать не в силах, и этот язык действует и в начале, и в конце действия только на интеллект (цит. по: [Там же, с. 98]).

С другой стороны, согласно идее множественности предикатов, живопись должна отражать все стороны жизни человека, не только «явление мышления с его процессами в голове этого человека», но и то, «как бьет кровь в его шее через щитовидную железу», а также его классовую принадлежность, борьбу за социальную справедливость и т. д.:

Основа моего искусства, то есть то, что я преимущественно наблюдаю, изучаю и выявляю в своих работах, это изучение человека, его интеллектуальных, классовых и биодинамических данных, свойств и процессов мышления и жизни, происходящих в нем (цит. по: [Там же, с. 102]).

${ }^{11}$ От частного (телесного), изменяющегося, эволюционирующего Филонов движется к общему (духовному), неизменному, к формуле материального содержания. Тело есть объект анализа, всегда приводящего к синтезу. Синтетичность Филонова и является залогом воссоединения тела и души [Йоффе, с. 525-526]. 
Филонов осмысляет не просто замкнутый человеческий организм или микрокосм, но и вписанность человека в мир, макрокосм. Новый перерожденный человек представлен на картине «Человек в мире» (1925), которая сочетает абстракцию формул (использование кристаллической структуры) и относительную реалистичность голов.

Голова является также отправной точкой картины «Формула империализма», написанной в том же 1925 г. Судя по названию, речь могла идти об изобличающей пропагандистской картине, где голова предстает как некий собирательный образ империалиста. Но такой образ не может интересовать Филонова, его привлекает более обширный феномен - сама идея империализма, которую он стремится выразить в так называемой формуле. При этом формула значительнее преходящей и изжившей себя формы человека-империалиста. Иначе говоря, формула империализма подразумевает у Филонова дальнейшую эволюцию и не может не вести к преобразованию в новой форме - например, к форме пролетария.

Если сравнить проект Филонова с художественной стратегией Платонова, то в их творчестве наблюдается диссоциация телесного и душевного, которая объясняется принадлежностью обоих проектов революционному времени. Переходный характер эпохи, радикальность разрыва с общепринятыми нормами представления, но также и вторжение новых правил, новой нормы - нормы насилия открывают поле для литературных и художественных экспериментов. Однако для авторов ценностью обладает не сам по себе разрушительный момент, но следующий за ним конструктивный период, то есть воссоздание нарушенного единства между телом и духом путем изобретения новой формы телесности. Доведение телесности и материальности до своего предела, до разложения, при котором они превращаются в свою противоположность-мысль, осознавание - исходный вектор движения обоих авторов.

\section{Список литературы}

Б. А. Выставка картин «Союза молодежи» в Петербурге // Огонек. 1913. № 48. С. 7. Гаспаров Б. Платонов и Решетников // Quaestio Rossica. 2014. № 2. C. 176-192.

Геллер Л. Платонов: революция, утопия, насилие // Поэтика Андрея Платонова : Скрытая теплота революции / под ред. Е. Яблокова. М. : Полимедиа, 2017. C. $7-24$.

Гюнтер X. По обе стороны от утопии : Контексты творчества А. Платонова. М. : Новое лит. обозрение, 2011. 208 с.

Дмитровская М. Философский контекст романа А. Платонова «Счастливая Москва» (Платон, Аристотель, О. Шпенглер) // Russian Literature. Vol. 46. 1999. № 2. C. $139-160$.

Иоффе И. Избранное : в 2 ч. М. : Говорящая книга, 2010. 655 с. Ч. 1. Синтетическая история искусств : Введение в историю художественного мышления.

Зльљднева Н. В. Страшное в живописи: случай Павла Филонова : Визуальный нарратив: опыт мифопоэтического прочтения. М. : Индрик, 2013. 360 с.

Матюшин М. В. Творчество Павла Филонова // Ежегодник рукописного отдела Пушкинского Дома на 1977. Л. : Наука, 1979. С. 232-235. 
Махов Н. М. Павел Филонов и его натурфилософия. М. : Лендант, 2015. 194 с.

Мислер Н. Разлагающийся образ: пять ступеней в творчестве Филонова // Павел Филонов : Очевидец незримого. СПб. : Palace Ed., 2006. С. 33-48.

Платонов А. А. Чевенгур // Платонов А. А. Собр. соч. : в 8 т. М. : Время, 2011. T. 3. C. $9-410$.

Платонов А. А. Джан // Платонов А. А. Собр. соч. : в 8 т. М. : Время, 2011. Т. 4. C. $111-234$.

Платонов А. А. Достоевский // Платонов А. А. Собр. соч. : в 8 т. М. : Время, 2011. T. 8. C. $12-13$.

Платонов А. А. Сокровенный человек // Платонов А. А. Собр. соч. : в 8 т. М. : Время, 2011. Т. 2. С. 161-235.

Подорога В. А. Мимесис : Материалы по аналитической антропологии литературы : в 2 т. М. : Культурная революция, 2011. Т. 2. Ч. 1. 605 с.

Сарабьянов Д. В. Павел Филонов среди современников и предшественников // Сарабьянов Д. В. Русская живопись. Пробуждение памяти. М. : Искусствознание, 1998. С. 381-388.

Филонов. Художник. Исследователь. Учитель : в 2 т. М. : Агей Томеш, 2006. Т. 2. 367 с.

Хаминова А. А., Зильберман Н. Н. Теория интермедиальности в контексте современной гуманитарной науки // Вестн. Томск. гос. ун-та. 2014. № 389. С. 38-45.

Filonov : Catalogue de l'exposition. Paris : Centre Georges Pompidou, 1990. 241 p.

Bowlt J. E. Pavel Filonov: His Painting and His Theory // The Russian Rev. Vol. 34. 1975. Jul. No. 3. P. 282-292.

\section{References}

B. A. (1913). Vystavka kartin "Soyuza molodezhi" v Peterburge [Exhibition of Paintings of the Union of Youth in St Petersburg]. In Ogonek. Vol. 48, p. 7.

Bowlt, J. E. (1975). Pavel Filonov: His Painting and His Theory. In The Russian Review. Vol. 34. July. No. 3, pp. 282-292.

Dmitrovskaya, M. (1999). Filosofskii kontekst romana A. Platonova "Schastlivaya Moskva" (Platon, Aristotel', O. Spengler) [Philosophical Context of A. Platonov's Novel Happy Moscow (Plato, Aristotle, O. Spengler)]. In Russian Literature. Vol. 46. No. 2, pp. 139-160.

Filonov. Catalogue de l'exposition. (1990). Paris, Centre Georges Pompidou. 241 p.

Filonov. Khudozhnik. Issledovatel'. Uchitel'v $2 t$. [Filonov. Artist. Researcher. Teacher. 2 Vols.]. (2006). Moscow, Agei Tomesh. Vol. 2. 367 p.

Gasparov, B. (2014). Platonov i Reshetnikov [Platonov and Reshetnikov]. In Quaestio Rossica. No. 2, pp. 176-192.

Günther, H. (2011). Po obe storony ot utopii. Konteksty tvorchestva A. Platonova [On Both Sides of Utopia. A. Platonov : Contexts of Creation]. Moscow, Novoe literaturnoe obozrenie. 208 p.

Heller, L. (2017). Platonov: revolyutsiya, utopiya, nasilie [Platonov: Revolution, Utopia, Violence]. In Yablokov, E. (Ed.). Poetika Andreya Platonova. Skrytaya teplota revolyutsii. Moscow, Polimedia, pp. 7-24.

Ioffe, I. (2010). Izbrannoe v $2 \mathrm{ch}$. Ch. 1. Sinteticheskaya istoriya iskusstv. Vvedenie $v$ istoriyu khudozhestvennogo myshleniya [Selected Writings. 2 Parts. Part 1. A Synthetic History of Art]. Moscow, Govoryashchaya kniga. 655 p.

Khaminova, A. A., Zil'berman, N. N. (2014). Teoriya intermedial'nosti v kontekste sovremennoi gumanitarnoi nauki [The Theory of Intermediality in the Context of the Contemporary Humanities]. In Vestnik Tomskogo gosudarstvennogo universiteta. No. 389, pp. 38-45.

Makhov, N. (2015). Pavel Filonov i ego naturfilosofiya [Pavel Filonov and His Natural Philosophy]. Moscow, Lendant. 194 p.

Matyushin, M. V. (1979). Tvorchestvo Pavla Filonova [Pavel Filonov's Creative Work]. In Ezhegodnik rukopisnogo otdela Pushkinskogo Doma na 1977 [Annals of the Manuscript Department of Pushkin House for the Year 1977]. Leningrad, Nauka, pp. 232-235. 
Misler, N. (2006). Razlagayushchiisya obraz: pyat' stupenei v tvorchestve Filonova [Decaying Image: Five Steps in Filonov's Creative Work]. In Pavel Filonov. Ochevidets nezrimogo. St Petersburg, Palace Editions, pp. 33-48.

Platonov, A. A. (2011). Chevengur [Chevengur]. In Platonov, A. A. Sobranie sochinenii $v 8$ t. Moscow, Vremya. Vol. 3, pp. 9-410.

Platonov, A. A. (2011). Dostoevskii [Dostoyevsky]. In Platonov, A. A. Sobranie sochinenii $v 8 t$. Moscow, Vremya. Vol. 8, pp. 12-13.

Platonov, A. A. (2011). Dzhan [Jan]. In Platonov, A. A. Sobranie sochinenii $v 8 t$. Moscow, Vremya. Vol. 4, pp. 111-234.

Platonov, A. A. (2011). Sokrovennyi chelovek [The Secret Person]. In Platonov, A. A. Sobranie sochinenii v 8 t. Moscow, Vremya. Vol. 2, pp. 161-235.

Podoroga, V. A. (2011). Mimesis. Materialy po analiticheskoi antropologii literatury $v$ $2 t$. [Mimesis. Materials for the Analytical Anthropology of Literature. 2 Vols.]. Moscow, Kul'turnaya revolyutsiya. Vol. 2. Part 1. 605 p.

Sarab'yanov, D. V. (1998). Pavel Filonov sredi sovremennikov i predshestvennikov [Pavel Filonov among his Contemporaries and Predecessors] In Sarab'yanov, D. V. Russkaya zhivopis'. Probuzhdenie pamyati. Moscow, Iskusstvoznanie, pp. 381-388.

Zlydneva, N. V. (2013). Strashnoe v zhivopisi: sluchai Pavla Filonova. Vizual'nyi narrativ: opyt mifopoeticheskogo prochteniya [The Horrible in Painting: The Case of Pavel Filonov. The Visual Narrative: An Essay of Mythopoetical Reading]. Moscow, Indrik. 360 p.

The article was submitted on 12.12 .2018 